\title{
Intermolecular interaction of thiosemicarbazone derivatives to solvents and a potential Aedes aegypti target
}

\section{João Bosco P. da Silva ${ }^{a}$,*, Fernando Hallwass ${ }^{a}$, Aluizio G. da Silva ${ }^{a}$, Diogo Rodrigo Moreira ${ }^{a, 1}$,} Mozart N. Ramos ${ }^{a}$, José Wanderlan P. Espíndola ${ }^{\mathrm{b}}$, Ana Daura T. de Oliveira ${ }^{\mathrm{b}}$, Dalci José Brondani ${ }^{\mathrm{b}}$, Ana Cristina L. Leite ${ }^{\mathrm{b}}$, Kenneth M. Merz Jr. ${ }^{c, 2}$

a Departamento de Química Fundamental, Centro de Ciências Exatas e da Natureza, Universidade Federal de Pernambuco, 50670-901 Recife, PE, Brazil

${ }^{\mathrm{b}}$ Departamento de Ciências Farmacêuticas, Centro de Ciências da Saúde, Universidade Federal de Pernambuco, 50740-521 Recife, PE, Brazil

' Quantum Theory Project, University of Florida, 2234 New Physics Building, PO Box 118435, Gainesville, FL, USA

\section{H I G H L I G H T S}

- Thiosemicarbazones (TSCZ)

derivatives exhibit large $A$. aegypti

larvicide activity.

- Semicarbazone (SCZ) derivatives exhibit low A. aegypti larvicide activity.

- The high ${ }^{1} \mathrm{H}$ NMR $\delta$ of NNH in TSCZ was in the literature credited to $\mathrm{H}$ bond to DMSO.

- Our NMR experiments and theoretical calculations shown NNH interactions with water.

- TSCZ and SCZ make distinct H-bond interaction to AeSCP-2's residues.

\section{A R T I C L E I N F O}

Article history:

Received 14 January 2015

Received in revised form 5 March 2015

Accepted 6 March 2015

Available online 20 March 2015

\section{Keywords:}

Thiosemicarbazone

Intermolecular interaction

Solvent

Aedes aegypti

AeSCP-2

DFT
G R A P H I C A L A B S T R A C T

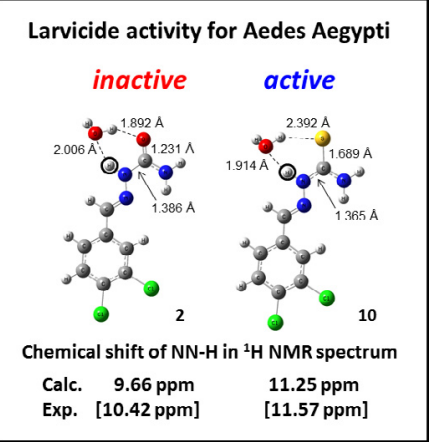

\section{A B S T R A C T}

DFT calculations were used to access information about structure, energy and electronic properties of series of phenyl- and phenoxymethyl-(thio)semicarbazone derivatives with demonstrated activity against the larvae of Aedes aegypti in stage L4. The way as the thiosemicarbazone derivatives can interact with solvents like DMSO and water were analyzed from the comparison between calculated and experimental ${ }^{1} \mathrm{H}$ NMR chemical shifts. The evidences of thiosemicarbazone derivatives making H-bond interaction to solvent have provide us insights on how they can interact with a potential A. aegypti's biological target, the Sterol Carrier Protein-2.

(ㄷ) 2015 Elsevier B.V. All rights reserved.

\footnotetext{
* Corresponding author. Tel.: +55 812126 7419; fax: +55 8121268442.

E-mail addresses: paraiso@ufpe.br, paraiso100@yahoo.com.br (J.B.P. da Silva).

1 Present address: Centro de Pesquisas Gonçalo Moniz - CPqGM, Rua Waldemar Falcão, 121, Candeal, $40296-710$ Salvador, BA, Brazil

2 Present address: Institute for Cyber Enabled Research, Department of Chemistry and the Department of Biochemistry and Molecular Biology, Michigan State University, 578 S. Shaw Lane, East Lansing, MI 48824, USA.
} 


\section{Introduction}

Dengue Fever (DF) is a serious disease caused by at least four virus serotypes (1-4) transmitted by Aedes aegypti (A. aegypti) mosquito [1,2]. Recently, a fifth serotype has been reported [3]. DF is principally related but not limited to tropical and subtropical regions of the world [4-9]. One strategy for the A. aegypti mosquito control is the use of chemical larvicides $[10,11]$.

As part of a systematic program for searching new larvacide agents against the $A$. aegypti larvae, recently our group has developed the synthesis of a series of semicarbazone and thiosemicarbazone derivatives (see Scheme 1) and test them against the larvae of $A$. aegypti in their fourth larvae stage (L4) [12,13]. The results point out for the improved larvicide activity of the thiosemicarbazone derivatives compared to the corresponding semicarbazone derivatives. For the thiosemicarbazones series, in particular, the phenoxymethyl derivatives have exhibited a higher larvicide performance than the corresponding aryl derivatives [13]. Nowadays, there is no thiosemicarbazone-based medicine already in use in humans. However, the anticancer thiosemicarbazone Triapine is under clinical trial investigation phase III [14].

In order to design the new generation of thiosemicarbazone derivatives with improved larvicide activity in Ref. 13 we used a Quantitative Structure Activity Relationship (QSAR) approach [15]. It is known that the successful of such approach is heavily depending on the quality of the response function (in our case the larvicide activity) and the selected descriptors. Since experimental descriptors tables are frequently incomplete for some substituents, many times these descriptors come from theoretical calculations. Because of that, in this work electronic structure calculations were developed in order to access structural (configurational and conformational aspects), energetic and electronic information for the synthesized (thio)semicarbazone derivatives. Parallel, NOESY ${ }^{1} \mathrm{H}$ NMR experiments for these compounds in DMSO- $d_{6}$ were conducted in order to strength the theoretical finds. The ability of the thiosemicarbazone's NN-H moiety to make intermolecular interactions was evaluated from the NMR analysis. Specifically, it was done by the comparison between theoretical predictions of the chemical shifts of (thio)semicarbazones-solvent hydrogen bonded complexes (H-complexes) and the corresponding experimental data. The comprehension on how these compounds interact to the solvent can provide us insights on how they can interacts with a potential biological target of the mosquito A. aegypti, the Sterol Carrier Protein-2 (AeSCP-2). Lan and co-workers have reported the X-ray structure of palmitic acid co-crystallized into AeSCP-2 [16]. These authors have proposed that the polar head of palmitic acid binds to the SCP-2's residues Arg24 and Glu25 through H-bonds. Because of that, the palmitic acid contact residues in SCP-2 were used as template to test the ability of the polar head $\left(-\mathrm{HC}=\mathrm{N}-\mathrm{NH}-(\mathrm{C}=\mathrm{X})-\mathrm{NH}_{2}, \quad \mathrm{X}=\mathrm{O}\right.$ or $\left.\mathrm{S}\right)$ of (thio)semicarbazone derivatives to form $\mathrm{H}$-bonds interaction as well. In order to check this hypothesis, formaldehyde-thiosemicarbazone and the protonated tripeptide $\mathrm{CH}_{3} \mathrm{CO}-\mathrm{Arg} 24\left(\mathrm{H}^{+}\right)-\mathrm{Gln} 25-$ Val26- $\mathrm{NHCH}_{3}$ were employed as interacting model systems.<smiles></smiles>

(E, comti)<smiles>[X]C(N)N/N=C/C(C)=C(C)c1ccccc1</smiles>

$1-10 \quad(E$, syn $)$

\begin{tabular}{cccc} 
Compound & $\mathbf{R}_{\mathbf{1}}$ & $\mathbf{n}$ & $\mathrm{X}$ \\
\hline 1 & $4-\mathrm{F}$ & 0 & 0 \\
2 & $3,4-d i \mathrm{Cl}$ & 0 & 0 \\
3 & $3-\mathrm{Br}, 4-\mathrm{NO}_{2}$ & 0 & $\mathrm{~S}$ \\
4 & $4-\mathrm{OH}$ & 0 & $\mathrm{~S}$ \\
5 & $3-\mathrm{CHNNHCSNH} \mathrm{H}_{2}$ & 0 & $\mathrm{~S}$ \\
6 & $4-\mathrm{F}$ & 0 & $\mathrm{~S}$ \\
7 & $4 \mathrm{Cl}$ & 0 & $\mathrm{~S}$ \\
8 & $\mathrm{H}$ & 1 & $\mathrm{~S}$ \\
9 & $4-\mathrm{Br}$ & 0 & $\mathrm{~S}$ \\
10 & $3,4-d i C l$ & 0 & $\mathrm{~S}$
\end{tabular}

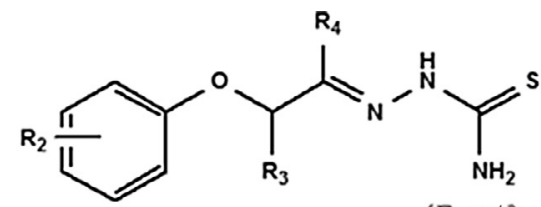

(E, anti)<smiles>[R]/C(=N\NC(N)=S)C([R9])Oc1c[R17]ccc1</smiles>

11-18 (E, syn $)$

\begin{tabular}{cccc} 
Compound & $\mathbf{R}_{2}$ & $\mathrm{R}_{3}$ & $\mathbf{R}_{\mathbf{4}}$ \\
\hline 11 & $4-\mathrm{OMe}$ & $\mathrm{H}$ & $\mathrm{H}$ \\
12 & $\mathrm{H}$ & $\mathrm{H}$ & $\mathrm{H}$ \\
13 & $3-\mathrm{Cl}$ & $\mathrm{H}$ & $\mathrm{H}$ \\
14 & $4-\mathrm{Br}$ & $\mathrm{H}$ & $\mathrm{H}$ \\
15 & $4-\mathrm{Cl}$ & $\mathrm{H}$ & $\mathrm{H}$ \\
16 & $2,3-d i \mathrm{Cl}$ & $\mathrm{H}$ & $\mathrm{H}$ \\
17 & $3,4-d i \mathrm{Cl}$ & $\mathrm{H}$ & $\mathrm{H}$ \\
18 & $3,4-d i \mathrm{Cl}$ & $\mathrm{Me}$ & $\mathrm{Me}$
\end{tabular}

Scheme 1. General representation of the possible configurations and conformations of the (thio)semicarbazone derivatives investigated in this work. 


\section{Methodology}

Computational

Electronic structure calculations of the isolated molecules 1-18 (for numbering see Scheme 1 or Fig. 1 in Ref. 13) and the H-bonded complexes between (thio)semicarbazone compounds and the solvent (DMSO or water) were performed with the density functional theory (DFT) method using the B3LYP [17] hybrid functional and the $6-311++G(d, p)$ basis set $[18,19]$. This basis set was selected because extended basis sets containing diffuse functions have been showed to be important for describing intermolecular interactions and in minimizing basis set superposition errors in systems making hydrogen bonds [20]. B3LYP/6-311++G(d,p) calculations were also used to calculate the H-bonded complex between and the model system formaldehyde-thiosemicarbazone and the tripeptide Arg24-GIn25-Val26. Harmonic infrared frequency calculations were developed to check the nature of the stationary points in the potential energy surface for those cases where the molecular geometry was optimized. The thermochemistry calculations were performed using standard procedures as described elsewhere [21]. The experimental geometry of the heavy atoms in the tripeptide Arg24-Gln25-Val26 was obtained from the PDB structure of AeSCP-2 co-crystallized with palmitic acid (1PZ4). The extreme peptide bonds of the tripeptide Arg24-Ln25-Val26 were completed with methyl groups. The methyl group was added using standard bond distances, bond angles and dihedral angles as defined in the GaussView 5 program [22]. Since the reported experimental structure of AeSCP-2 [16] was obtained at $\mathrm{pH}=7.4$, the Arg24 residue was considered protonated on the calculations. Thus, the domain of AeSCP-2 for interacting with our ligands was represented by $\mathrm{CH}_{3} \mathrm{CO}-\mathrm{Arg} 24\left(\mathrm{H}^{+}\right)-\mathrm{Gln} 25-\mathrm{Val26}-\mathrm{NHCH}_{3}$. All atoms in the $\mathrm{CH}_{3} \mathrm{CO}-\mathrm{Arg} 24\left(\mathrm{H}^{+}\right)-\mathrm{G} \ln 25-\mathrm{Val} 26-\mathrm{NHCH}_{3}$ were maintained frozen whereas the geometry of the model system (formaldehyde-thiosemicarbazone) representing the thiosemicarbazone derivatives was fully optimized during the intermolecular interaction. The ${ }^{1} \mathrm{H}$ NMR chemical shifts were calculated using the GIAO method [23]. All calculations were performed with the Gaussian09 program [24] using its default convergence criteria.

NMR

The ${ }^{1} \mathrm{H}$ and ${ }^{13} \mathrm{C}$ NMR were performed for 1-18 in DMSO- $d_{6}$ at $298 \mathrm{~K}$, using Agilent spectrometer $\left(400 \mathrm{MHz}\right.$ for ${ }^{1} \mathrm{H}, 100 \mathrm{MHz}$ for ${ }^{13} \mathrm{C}$ ) or Bruker AMX (300 MHz for ${ }^{1} \mathrm{H}, 75.5 \mathrm{MHz}$ for ${ }^{13} \mathrm{C}$ ). DEPT analysis was carried out to assigning carbon chemical shift unambiguously, as well as the addition of $\mathrm{D}_{2} \mathrm{O}$ for assigning $\mathrm{NH}$ signals in the ${ }^{1} \mathrm{H}$ NMR spectra. Tetramethylsilane was used as internal Ref. [13]. In this work NOESY spectra were acquired using a spectral width of $4.4 \mathrm{kHz}$, acquisition time $0.93 \mathrm{~s}, 2048 \times 128$ data points
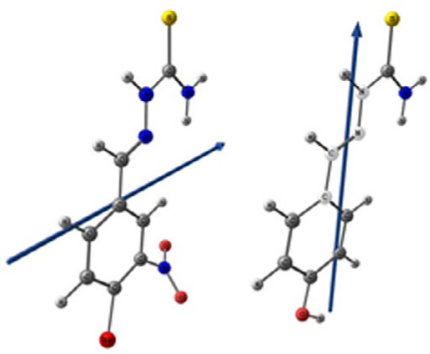

$\mu=4.23 \mathrm{D}$ $D(N N C C)=179.9^{\circ}$ $\mu=6.02 \mathrm{D}$ $D(N N C C)=179.9^{\circ}$
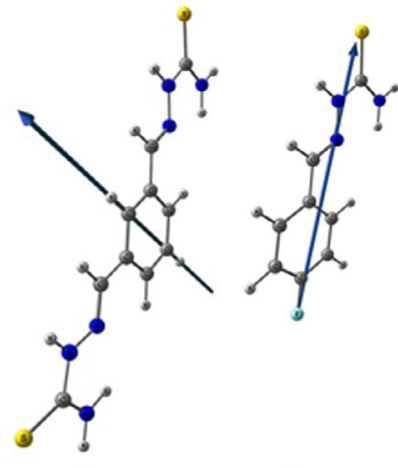

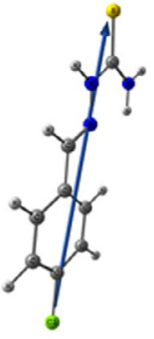

7 $\mu=4.28 \mathrm{D}$

$D(N N C C)=180.0^{\circ}$

\begin{abstract}
$\mu=3.700$
$D(N N C C)=180.0^{\circ}$
\end{abstract}

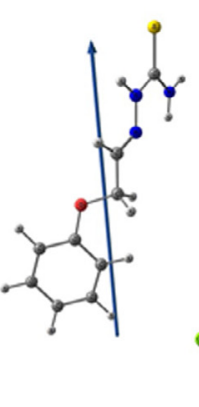

12

$\mu=4.82 \mathrm{D}$

$\mu=5.92 \mathrm{D}$

$D(N C C O)=-128.4^{\circ} \quad D(N C C O)=-128.1^{\circ}$

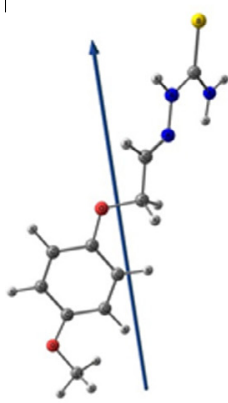

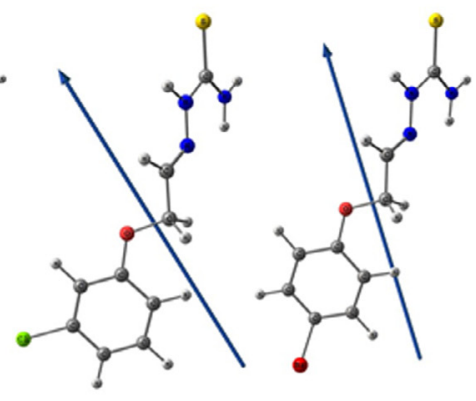

13

$\mu=4.66 \mathrm{D}$

$D(N C C O)=-126.6^{\circ}$

$D(N C C O)=-126.2^{\circ}$
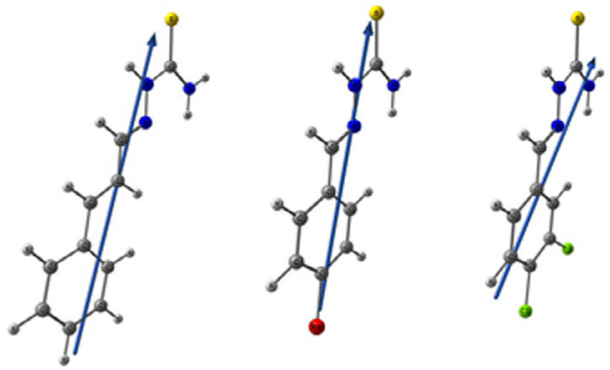

10 $\mu=3.13 \mathrm{D}$ $D(N N C C)=180.0^{\circ}$

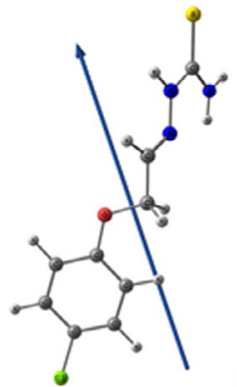

15

$\mu=2.94 \mathrm{D}$

$D(N C C O)=-126.5^{\circ}$
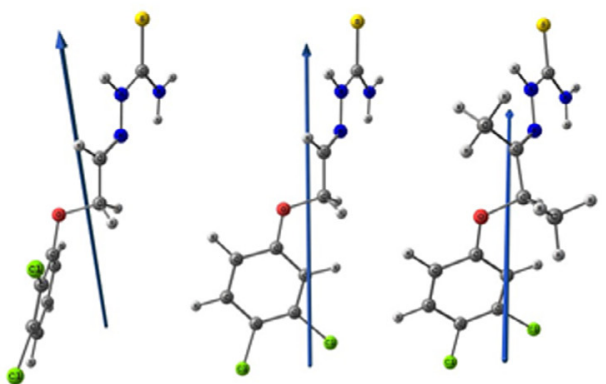

8

$\mu=3.31 \mathrm{D}$

$D(N C C O)=-129.3^{\circ}$

\section{Atom label Hydrogen Carbon}

Nitrogen

Oxygen

- Sulfur

- Chlorine

Bromine

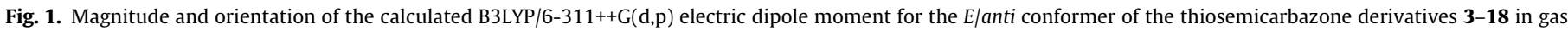
phase. Dihedral angle between the aryl-/phenoxy- and thiosemicarbazone chemical moieties, in degrees. 
in F1 and F2 dimensions, respectively, 32 scans and mixing time $1.5 \mathrm{~s}$.

\section{Results and discussions}

Molecular modeling of the isolated (thio)semicarbazone derivatives

The first step for modeling these (thio)semicarbazone derivatives was to investigate their configurational ( $E$ or $Z$ at the aryl $-\mathrm{C}=\mathrm{N}$ double bond) and conformational (syn or anti around the partial $\mathrm{NH}-\mathrm{CX}$ double bond, $\mathrm{X}=\mathrm{O}$ or $\mathrm{S}$ ) isomers (see Scheme 1 ).

Since the compounds studied in this work have three chemical domains, namely the thio- or semicarbazone group (X), the substituent at the aryl $\left(R_{1}\right)$ or phenoxy ring $\left(R_{2}\right)$, and the spacer unit $-\mathrm{CH}=$ or $-\mathrm{OCH}_{2} \mathrm{CH}=(\mathrm{SU})$ between the $\mathrm{X}$ and $\mathrm{R}-\mathrm{Ar}$ groups, then each compound will be represented by the triad $(\mathrm{R} ; \mathrm{SU} ; \mathrm{X})$ whereas the corresponding H-complex with the solvent by [R;SU;X]-solvent, where solvent $=\mathrm{H}_{2} \mathrm{O}$ or DMSO.

A review in the literature about the X-ray structures of $p$-fluorobenzaldehyde thiosemicarbazones [25], 3- and 4-R-pyridine thiosemicarbazones (with $\mathrm{R}=$ formyl and acetyl) [26], 4-R-pyridine $N(4)$-methyl and 4-R-pyridine $N(4)$-ethylthiosemicarbazones (with $\mathrm{R}=$ formyl and acetyl) [27] and 2-acetylthiophene thiosemicarbazones [28], indicate only the $E$ isomer for the $\mathrm{C}=\mathrm{N}$ moiety. It is confirmed by our NOESY spectra (see NMR section). The correlations of $\mathrm{NN}-\mathrm{H} / \mathrm{C}-\mathrm{H}$ have indicated that these protons are located on the same side of the molecule. Because of that, we have assumed the $E$ configuration for the $\mathrm{C}=\mathrm{N}$ moiety (as depictured at the Scheme 1) in all cases. On the other hand, the anti/syn conformational stability around the partial HNCS double bond was evaluated through the calculation of the standard Gibbs free energy for both (syn and anti) conformers as one can see in Table 1. The electric dipole moment and the lowest harmonic vibrational frequency are also showed in this table in order to check the polarity and the nature for each conformer in the potential energy surface, respectively.

From this table it is possible to see that both syn and anti conformers represent minima in the potential energy surface. The anti conformer is predicted to be the most stable one in average for ca.7.3 kcal mol${ }^{-1}$ and $9.3 \mathrm{kcal} \mathrm{mol}^{-1}$ for the semicarbazone (1-2) and thiosemicarbazone (3-18) derivatives, respectively. It is also possible to note that this energy difference do not depend on both the nature of the substituent $(\mathrm{R})$ at the aromatic ring or even on the nature of the spacer unit ( $\mathrm{SU}$, i.e., $-\mathrm{CH}=,-\mathrm{O}-\mathrm{CH}_{2}-\mathrm{CH}=$ or $\left.-\mathrm{O}-\mathrm{CH}\left(\mathrm{CH}_{3}\right)-\mathrm{CCH}_{3}=\right)$ between the aromatic ring and the (thio)semicarbazone moieties.

In order to help the polarity data analysis (Table 1), we have additionally developed B3LYP/6-311++G(d,p) calculations to obtain the electric dipole moment $(\mu)$ for urea $(\mu=3.88 \mathrm{D})$, thiourea $(\mu=5.00 \mathrm{D})$, formaldehyde-thiosemicarbazone $(\mu=4.50 \mathrm{D})$, and phenyl-thiosemicarbazone ( $\mu=5.46 \mathrm{D})$. See the structure of these four compounds in the Supplementary Data. In comparison for the last three compounds one can conclude that the hydrazone or the phenyl-hydrazone moieties do not modify too much the magnitude and the orientation of the electric dipole moment. From Table 1 some aspects about the electric dipole moment can be stressed. First, the thiosemicarbazones are predicted to exhibit higher electric dipole moment than the corresponding semicarbazone derivatives. In fact the difference of electric dipole moment between thiourea and urea, $1.1 \mathrm{D}$ is approximately maintained between the most stable forms of $\mathbf{6}$ and $\mathbf{1}, 1.3 \mathrm{D}$, and between $\mathbf{1 0}$ and 2, 1.5 D. Second and mainly for those with substituents at para position, the most stable anti conformer has a lower electric dipole moment than the corresponding syn conformer. The exceptions are the compounds non-substituted at the para position, 8 and $\mathbf{1 2}$, whereas the electric dipole moments are almost the same for both conformers and the compounds which the substituents may exhibit different orientation relative the $\mathrm{C}=\mathrm{S}$ bond, e.g. $4(\mathrm{R}=4-\mathrm{OH})$ and $11\left(\mathrm{R}=4-\mathrm{OCH}_{3}\right)$ and $\mathbf{1 6}(\mathrm{R}=3,4-\mathrm{DiCl})$ where their dipole bond for the minima structures leads to higher total dipole moment in the anti conformer. Of course, low electric dipole moment value for the most stable (anti) form of the thiosemicarbazone derivatives can be an advantageous aspect for promoting hydrophobic interaction in the biological environment. As any vector descriptor, besides the magnitude, the electric dipole moment vector has also a direction. Because of that, in Fig. 1 the direction of the electric

Table 1

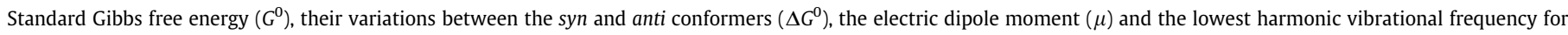
compounds 1-18 evaluated at B3LYP/6-311++G(d,p) level in the gas phase approach. All values were computed at $298.15 \mathrm{~K}$ and 1 bar. ${ }^{\text {a }}$

\begin{tabular}{|c|c|c|c|c|c|c|c|c|}
\hline \multirow[t]{2}{*}{ Number } & \multirow[t]{2}{*}{ Compound (R;SU;X) } & \multicolumn{3}{|l|}{ Syn } & \multicolumn{3}{|l|}{ Anti } & \multirow[t]{2}{*}{$\Delta \mathrm{G}^{0 \mathrm{a}}\left(\mathrm{kcal} \mathrm{mol}{ }^{-1}\right)^{\mathrm{b}}$} \\
\hline & & $G^{0}\left(\varepsilon_{\mathrm{H}}\right)$ & $\mu(\mathrm{D})$ & $v_{1}\left(\mathrm{~cm}^{-1}\right)$ & $G^{0}\left(\varepsilon_{\mathrm{H}}\right)$ & $\mu(\mathrm{D})$ & $v_{1}\left(\mathrm{~cm}^{-1}\right)$ & \\
\hline 1 & $(4-\mathrm{F} ; \mathrm{CH} ; \mathrm{O})$ & -649.045519 & 5.61 & 42.0 & -649.057077 & 2.38 & 33.4 & -7.25 \\
\hline 2 & $(3,4-\mathrm{DiCl} ; \mathrm{CH} ; \mathrm{O})$ & -1469.031055 & 5.37 & 32.5 & -1469.042708 & 1.65 & 26.8 & -7.31 \\
\hline 3 & $\left(3-\mathrm{NO}_{2}, 4-\mathrm{Br} ; \mathrm{CH} ; \mathrm{S}\right)$ & -3650.829505 & 5.34 & 24.7 & -3650.843120 & 4.26 & 24.3 & -8.54 \\
\hline 4 & $(4-\mathrm{OH} ; \mathrm{CH} ; \mathrm{S})$ & -947.968453 & 4.35 & 34.1 & -947.983487 & 6.02 & 37.2 & -9.43 \\
\hline 5 & $(5-\mathrm{FTSC} ; \mathrm{CH} ; \mathrm{S})^{\mathrm{C}}$ & -1513.220541 & 4.63 & 16.3 & -1513.234814 & 4.28 & 15.1 & -8.96 \\
\hline 6 & $(4-\mathrm{F} ; \mathrm{CH} ; \mathrm{S})$ & -972.000578 & 6.06 & 33.8 & -972.015363 & 3.70 & 37.0 & -9.28 \\
\hline 7 & $(4-\mathrm{Cl} ; \mathrm{CH} ; \mathrm{S})$ & -1332.356854 & 6.11 & 35.4 & -1332.371675 & 3.50 & 35.0 & -9.30 \\
\hline 8 & $(\mathrm{H} ; \mathrm{CH}=\mathrm{CH}-\mathrm{CH} ; \mathrm{S})$ & -950.118099 & 5.96 & 26.1 & -950.134200 & 5.97 & 31.0 & -10.10 \\
\hline 9 & $(4-\mathrm{Br} ; \mathrm{CH} ; \mathrm{S})$ & -3446.278182 & 6.11 & 35.6 & -3446.293100 & 3.50 & 32.1 & -9.36 \\
\hline 10 & (3,4-DiCl;CH;S) & -1791.985694 & 5.43 & 25.5 & -1792.000329 & 3.13 & 29.4 & -9.18 \\
\hline 11 & $\left(4-\mathrm{OCH}_{3} ; \mathrm{OCH}_{2} \mathrm{CH} ; \mathrm{S}\right)$ & -1101.768777 & 4.03 & 19.4 & -1101.783947 & 5.92 & 17.4 & -9.52 \\
\hline 12 & $\left(\mathrm{H} ; \mathrm{OCH}_{2} \mathrm{CH} ; \mathrm{S}\right)$ & -987.243034 & 4.88 & 24.0 & -987.258250 & 4.82 & 22.4 & -9.54 \\
\hline 13 & $\left(3-\mathrm{Cl} ; \mathrm{OCH}_{2} \mathrm{CH} ; \mathrm{S}\right)$ & -1446.877531 & 4.20 & 16.9 & -1446.892287 & 4.66 & 18.7 & -9.26 \\
\hline 14 & $\left(4-\mathrm{Br} ; \mathrm{OCH}_{2} \mathrm{CH} ; \mathrm{S}\right)$ & -3560.798445 & 5.57 & 17.5 & -3560.813237 & 2.93 & 15.9 & -9.28 \\
\hline 15 & $\left(4-\mathrm{Cl} ; \mathrm{OCH}_{2} \mathrm{CH} ; \mathrm{S}\right)$ & -1446.876855 & 5.58 & 19.5 & -1446.891718 & 2.94 & 17.4 & -9.32 \\
\hline 16 & $\left(2,3-\mathrm{DiCl} ; \mathrm{OCH}_{2} \mathrm{CH} ; \mathrm{S}\right)$ & -1906.501534 & 3.30 & 13.3 & -1906.515805 & 5.52 & 15.9 & -8.96 \\
\hline 17 & $\left(3,4-\mathrm{DiCl} ; \mathrm{OCH}_{2} \mathrm{CH} ; \mathrm{S}\right)$ & -1906.505957 & 5.27 & 15.3 & -1906.520747 & 1.77 & 18.3 & -9.28 \\
\hline 18 & $\left(3,4-\mathrm{diCl} ; \mathrm{OCH}\left(\mathrm{CH}_{3}\right) \mathrm{CCH}_{3} ; \mathrm{S}\right)$ & -1985.111237 & 7.57 & 15.1 & -1985.126804 & $3.31^{d}$ & 14.7 & -9.77 \\
\hline
\end{tabular}

a The optimized geometries are available in the Supplementary Data.

b $\Delta G^{0}=G^{0}($ anti $)-G^{0}($ syn $)$.

c FTSC means formaldehyde-thiosemicarbazone ( $E$, anti).

${ }^{d}$ Ref. [13]. 
dipole moment for the E/anti conformer minima structures of 3-18 are shown. The pictures of $\mu$ for compounds $\mathbf{1}$ and $\mathbf{2}$ were not included because their directions are quite similar to $\mathbf{6}$ and $\mathbf{1 0}$, respectively.

Fig. 1 confirms the chemical feeling that, except by the effect of the nitro and the formy-thiosemicarbazone groups in $\mathbf{3}$ and $\mathbf{5}$, respectively, the electric dipole moment is mainly orientated toward the $\mathrm{C}=\mathrm{S}$ chemical bond for all the systems investigated. It is interesting to note that the compounds with large dipole moments 3-5, 11 and 12 did not also show good larvicide activity [13]. The introduction of a halogen substituent at the para position (therefore in the opposite direction to the $\mathrm{C}=\mathrm{S}$ dipole bond) decreases the electric dipole moment in 1.8-2.0 $\mathrm{D}$ but maintains its orientation for the para- $\mathrm{R}_{1}$-aryl-thiosemicarbazone derivatives (6, 7 and 9) relative to the non-substituted phenyl-thiosemicarbazone $(\mu=5.46 \mathrm{D})$. The same decreasing effect due to halogen atoms in the para position is observed for the para- $\mathrm{R}_{2}$-phenoxymethyl-thiosemicarbazone derivatives (14 and 15 ) relative 12, however with a clear change of the electric dipole moment orientation out the $\mathrm{C}=\mathrm{S}$ bond toward the oxygen atom on the phenoxymethyl moiety. This change is clearly related to the $-\mathrm{O}-\mathrm{CH}_{2}-\mathrm{CH}=$ spacer which have created a torsion (in the range of $-123.7^{\circ}$ to $-129.3^{\circ}$ ) between the thiosemicarbazide and phenoxymethyl fragments. Furthermore, the introduction of a second chlorine atom at the meta position decrease even more the electric dipole moment. It goes from $3.50 \mathrm{D}$ in $\mathbf{7}(\mathrm{X}=4-\mathrm{Cl})$ to $3.13 \mathrm{D}$ in $\mathbf{1 0}$ $(\mathrm{X}=3,4-\mathrm{DiCl})$ and from $2.94 \mathrm{D}$ in $15(\mathrm{X}=4-\mathrm{Cl})$ to $1.77 \mathrm{D}$ in 17 $(\mathrm{X}=3,4-\mathrm{DiCl})$.

\section{(Thio)semicarbazones-solvent interaction}

The ability to make intermolecular hydrogen bond (H-bond) interactions in solid state to both hydrogen donor $(\mathrm{NN}-\mathrm{H})$ and hydrogen acceptor $(\mathrm{C}=\mathrm{O}$ or $\mathrm{C}=\mathrm{S})$ sites have been reported in the literature to the semicarbazones (e.g. for (E)-1-(4-fluorophenyl)ethan-1-one semicarbazone [29]) and thiosemicarbazone (e.g. 2-acethylpyridine thiosemicarbazones [30]) compounds which are structurally similar to those investigated in this work. Besides, the ability to form $\mathrm{H}$-bonds in solution, in particular to the solvent, have been claimed as the responsible for increasing the chemical shift of $\mathrm{NN}-\mathrm{H}$ in ${ }^{1} \mathrm{H}$ NMR spectrum of 4-R-pyridineN(4)-methyl and 4-R-pyridineN(4)-ethylthiosemicarbazones (with $\mathrm{R}=$ formyl and acetyl) [27] and for 2-, 3- and 4-R-pyridine thiosemicarbazones (with $\mathrm{R}=$ formyl and acetyl) in DMSO- $d_{6}[31,32]$. However, since DMSO is a compound capable of hydration [33] the contribution of trace water molecules for the high $\mathrm{NN}-\mathrm{H}^{1} \mathrm{H}$ NMR chemical shift of our synthesized (thio)semicarbazone derivatives needs to be better investigated. Naturally, probing the $\mathrm{H}$-complexes formed between (thio)semicarbazone derivatives and DMSO or water may give us insights about how they can form $\mathrm{H}$-bond interaction to other relevant systems like aminoacid residues in proteins. Thus, in Fig. 2 the experimental and calculated $\mathrm{NN}-\mathrm{H}{ }^{1} \mathrm{H}$ NMR chemical shift for the (thio)semicarbazones (118) are showed.

From this figure some aspects are worth to be stressed. First of all, the range of experimental $\mathrm{NN}-\mathrm{H}^{1} \mathrm{H}$ NMR chemical shift values for our synthesized compounds $10.24-11.65 \mathrm{ppm}$ (in DMSO- $d_{6}$ ) are in complete agreement with previously published values for p-fluorobenzaldehyde (thio)semicarbazones (in DMSO- $d_{6}$ between $10.92 \mathrm{ppm}$ and $11.80 \mathrm{ppm}$, being $11.40 \mathrm{ppm}$ for 1) [25], 4-R-pyridineN(4)-methyl and 4-R-pyridineN(4)-ethylthiosemicarbazones (with $\mathrm{R}=$ formyl and acetyl) (in DMSO- $d_{6^{-}}$between $10.48 \mathrm{ppm}$ to $11.93 \mathrm{ppm}$ ) [27] and for 2-, 3- and 4-R-pyridine thiosemicarbazones (with $\mathrm{R}=$ formyl and acetyl) (in DMSO- $d_{6^{-}}$ between $10.45 \mathrm{ppm}$ and $11.67 \mathrm{ppm}$ ) [31,32]. Second, still for the experimental values one can see that the two semicarbazone $(\mathrm{X}=\mathrm{O})$ derivatives $\mathbf{1}$ and 2 have lower $\mathrm{NN}-\mathrm{H}{ }^{1} \mathrm{H}$ NMR chemical shifts (10.24 and $10.42 \mathrm{ppm}$, respectively) than any of the thiosemicarbazone $(X=S)$ derivative 3-18 (11.25-11.65 ppm). Third, for the thiosemicarbazone derivatives there are two levels of chemical shifts, the first eight one (3-10) and the following next seven one (11-17) that show $\mathrm{R}$ dependent (with $\mathrm{SU}=-\mathrm{CH}=$, which allows a larger delocalization) and $\mathrm{R}$ independent (with $\mathrm{SU}=$ phenoxymethyl, which represents an obstacle for the electron delocalization) chemical shift values, respectively. Curiously, the compound 18 (the methyled form of 17) exhibits a much lower experimental $\mathrm{NN}-\mathrm{H}$ chemical shift value $(10.19 \mathrm{ppm})$ when compared to the previous thiosemicarbazone derivatives (3-17).

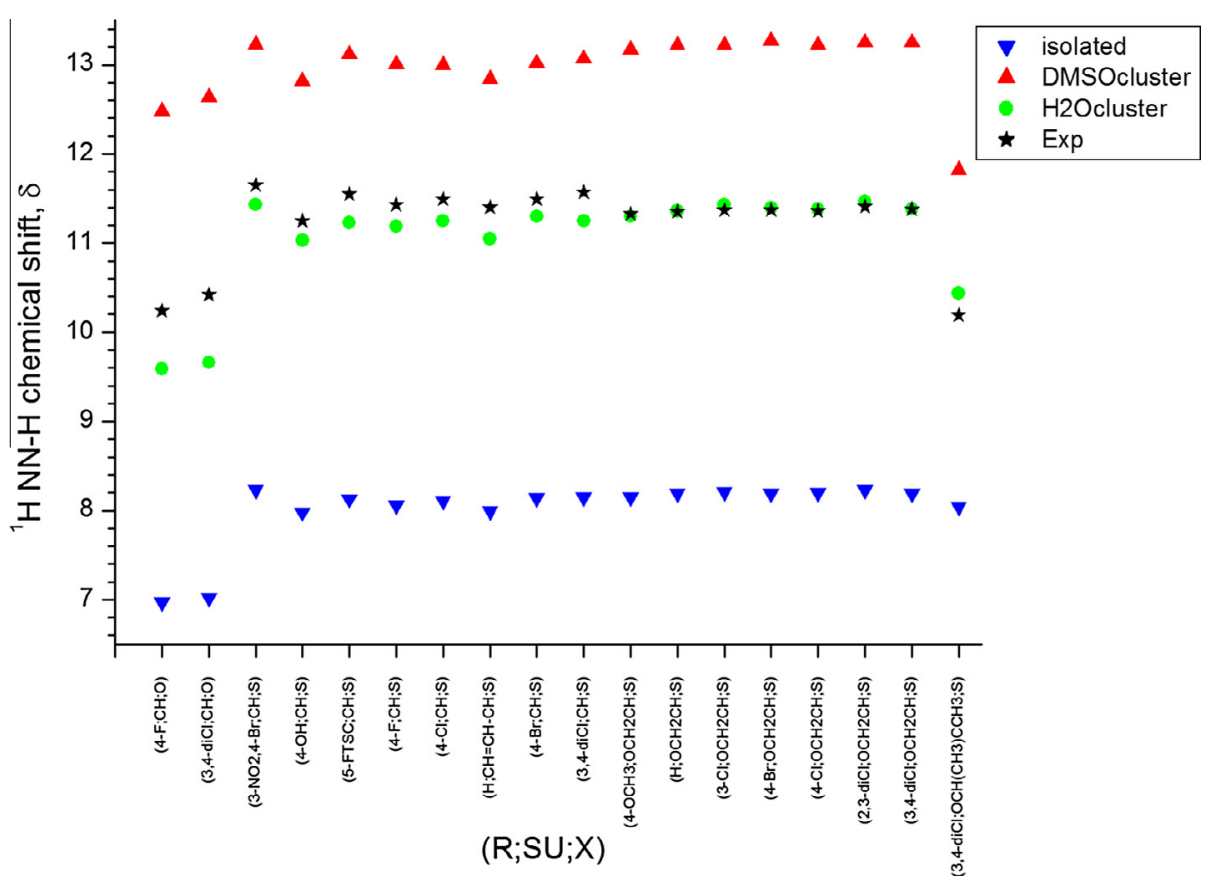

Fig. 2. Experimental (in DMSO- $d_{6}$ ) and calculated B3LYP/6-311++G(d,p) ${ }^{1} \mathrm{H} \mathrm{NN}-\mathrm{H}$ chemical shift of (thio)semicarbazone derivatives (1-18). 
Fourth, it is possible to observe that the isolated molecule model is not useful to predict the $\mathrm{NN}-\mathrm{H}{ }^{1} \mathrm{H}$ NMR chemical shift since it underestimates the experimental values. Nevertheless, the isolated molecule model works in describing the chemical shifts of $\mathrm{NN}-\mathrm{H}$ in semicarbazones as being more deshielded than in the thiosemicarbazone derivatives. However, it does not succeed for predicting the chemical shift for $\mathbf{1 8}$ since its value is essentially the same for 3-17. On the other hand, the $\mathrm{NN}-\mathrm{H}$ chemical shift prediction is much more close to the experimental values when the H-complex (thio)semicarbazone-solvent model is used. Concerning the $\mathrm{H}-$ complex model, it is interesting to observe that water perform better than DMSO as solvent for correlating calculated and experimental chemical shift values. In fact, the rms deviation between calculated and experimental $\mathrm{NN}-\mathrm{H}$ chemical shifts for the (thio)semicarbazone derivatives $-\mathrm{H}_{2} \mathrm{O}$ complexes is $0.30 \mathrm{ppm}$ whereas it is $1.76 \mathrm{ppm}$ for the (thio)semicarbazone derivativesDMSO complexes. Moreover, the remarkable difference on the experimental $\mathrm{NN}-\mathrm{H}{ }^{1} \mathrm{H}$ NMR chemical shifts of semicarbazones and thiosemicarbazones derivatives can be better understood based on the structure of the (thio)semicarbazone derivatives$\mathrm{H}_{2} \mathrm{O}$ complexes (see Fig. 3).

Since the CS bond distance ( $c a .1 .69 \AA$ ) is larger than the CO bond distance ( $c a .1 .23 \AA$ ) it is waited that the weight of the $\mathrm{C}^{+}-\mathrm{S}^{-}$structure being larger than the $\mathrm{C}^{+}-\mathrm{O}^{-}$one. As consequence, it is also waited that the behavior of the adjacent partial double bond and the acidity of $\mathrm{NN}-\mathrm{H}$ is larger in the thiopeptidic environment than in the peptidic counterpart. This can by itself justify the larger experimental $\mathrm{NN}-\mathrm{H}$ chemical shift of thiosemicarbazone compared to semicarbazone derivatives. However and even much more interesting, it suggests that water molecules interact in a different way in semicarbazone and thiosemicarbazone derivatives. From Fig. 3 it is clear that the replacement of carbonyl in $\mathbf{2}$ by thiocarbonyl bond in $\mathbf{1 0}$ leads to a strengthening of $\mathrm{NN}-\mathrm{H}-\mathrm{OH}_{2}$ and a weakening of $\mathrm{HOH}-\mathrm{X}=\mathrm{C} \mathrm{H}$-bonds. That is the reason why the calculated or experimental $\mathrm{NN}-\mathrm{H}^{1} \mathrm{H}$ NMR chemical shift is larger for thiosemicarbazone than for semicarbazone derivatives (see Fig. 3). Note that these two H-bond distances are essentially the same no matter the nature of SU (compare $\mathbf{1 0}$ and 17). Finally, taking in account both Figs. 2 and 3 it is also clear that the presence of methyl groups in 18 decreases the $\mathrm{NN}-\mathrm{H}$ chemical shift principally by a steric effect. Observe that the $\mathrm{NN}-\mathrm{H}-\mathrm{OH}_{2}$ bond distance values $1.907 \AA$ in $\mathbf{1 7}$ whereas it values $1.951 \AA$ in $\mathbf{1 8}$. This hypothesis can be supported by NMR experiments. The NOESY spectrum for thiosemicarbazone shows correlation peaks for $\mathrm{NN}-\mathrm{H} /$ water signals (Fig. 4). These correlations are due to chemical exchange processes that are taken place, indicating $\mathrm{H}$-bonds formation. These correlations peaks were observed when the thiosemicarbazone derivative 10 was analyzed (dotted circles in Fig. 4b). On the other hand, these correlations were not observed when the same experiment is performed with the semicarbazone derivative $\mathbf{2}$ (Fig. 4a).

The different ways as thiosemicarbazone and semicarbazone interact with the solvent can be of relevance for their biological activity. This is so if the differences that feature the way as thiosemicarbazone and semicarbazone interact with the solvent are assumed to be the same in a protein environment. In fact, the higher larvicidal activity observed for thiosemicarbazone derivatives [13] can be nicely rationalized in terms of the larger ability its $\mathrm{NNH}$ group to form $\mathrm{H}$-bond interaction to protein residues compared to semicarbazone derivatives. In a such scenario, amino acid residues that can form $\mathrm{H}$-bond interaction, in particular those that resemble the (thio)semicarbazone moiety (e.g. Asp, Gln, Arg) became natural candidates for intermolecular interactions as will be discussed in the next section.

\section{Hydrogen bond interaction to AeSCP-2}

It has been proposed that the polar head of palmitic acid binds to SCP-2's residues Arg24 and Glu25 through H-bonds whereas to methylenic tail to the residues Val26, Leu45, Met46, Leu102, Ile99, Leu64, Met90, Met66, Ile74, Phe32, Met71, Ile12, Ile106, Phe105, Ser108 and Leu16 through hydrophobic interactions [16]. Because in the previous section we have theoretically and experimentally proofed that the polar head of (thio)semicarbazone derivatives has the ability to form $\mathrm{H}$-bonds to solvents like DMSO or water, we have used the palmitic acid's contact residues in SCP-2 as template for our compounds. Fig. 5 shows the B3LYP/6$311++G(d, p)$ optimized structures representing the four different ways on which the simplified model system formaldehydethiosemicarbazone can form $\mathrm{H}$-bonds to the protonated tripeptidic system $\mathrm{CH}_{3} \mathrm{CO}-\mathrm{Arg} 24\left(\mathrm{H}^{+}\right)-\mathrm{Gln} 25-\mathrm{Val} 26-\mathrm{NHCH}_{3}$.

From Fig. 5 one can observe that formaldehyde-thiosemicarbazone can make $\mathrm{H}$-bond interaction with the protonated tripeptide model system $\mathrm{CH}_{3} \mathrm{CO}-\mathrm{Arg} 24\left(\mathrm{H}^{+}\right)-\mathrm{Gln} 25-\mathrm{Val} 26-\mathrm{NHCH}_{3}$ through four different ways. In each case the sulfur atom points toward a set of $\mathrm{N}-\mathrm{H}$ bonds (two of them related to the protonated $\operatorname{Arg} 24\left(\mathrm{H}^{+}\right)$side chain and two related to the peptide bond of $\mathrm{Gln} 25$

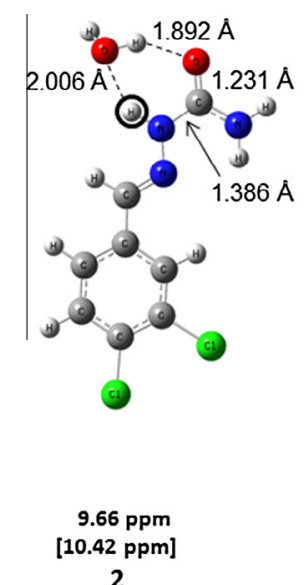

2
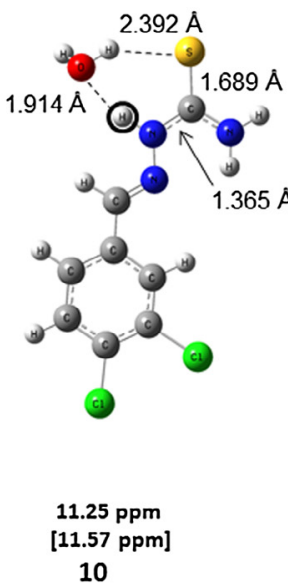

11.25 ppm
$[11.57 \mathrm{ppm}]$

10

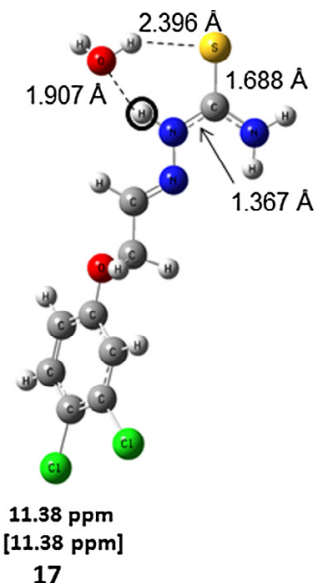

17

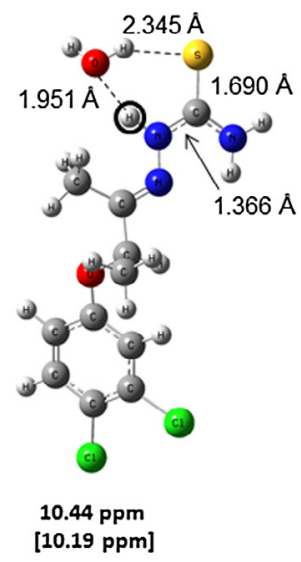

18

Atom label $\checkmark$ Hydrogen Carbon Nitrogen Oxygen - Sulfur $\bullet$ Chlorine

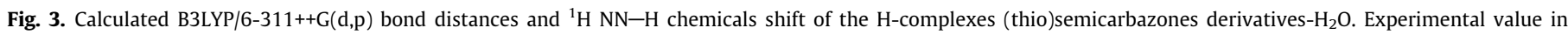
brackets. 


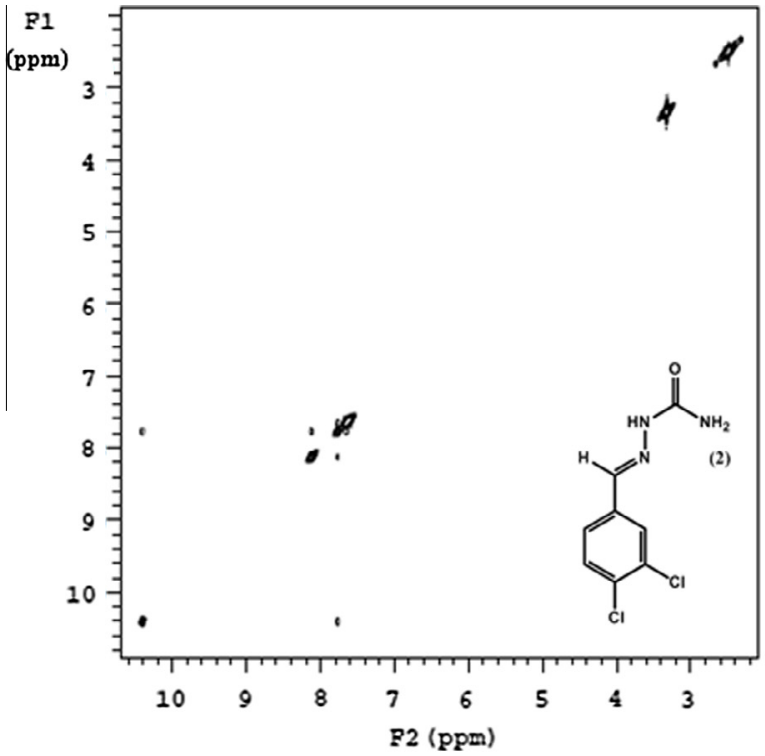

(a)

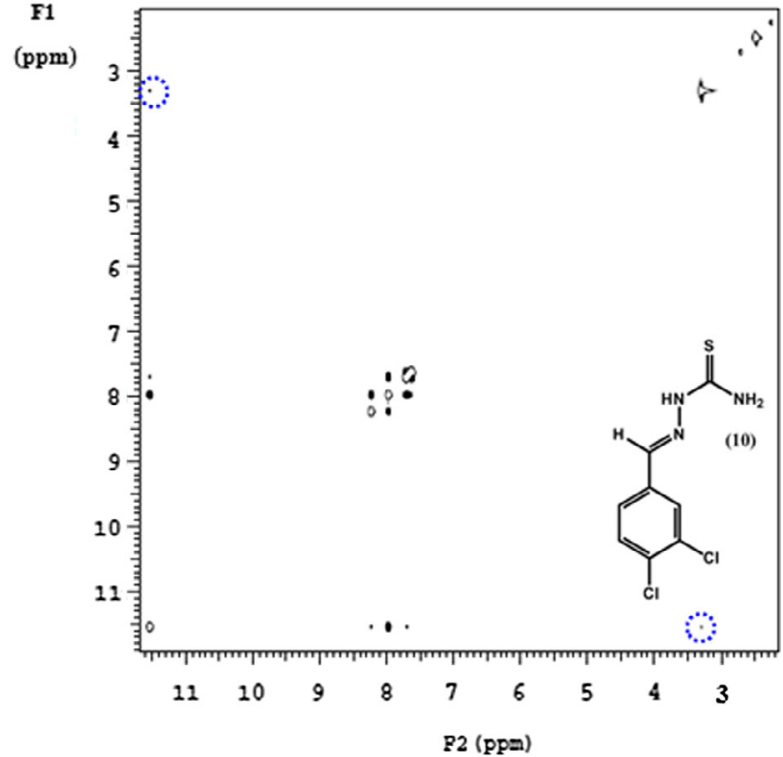

(b)

Fig. 4. NOESY spectra ( $400 \mathrm{MHz})$ in DMSO- $d_{6}$ of: (a) 2 and (b) 10

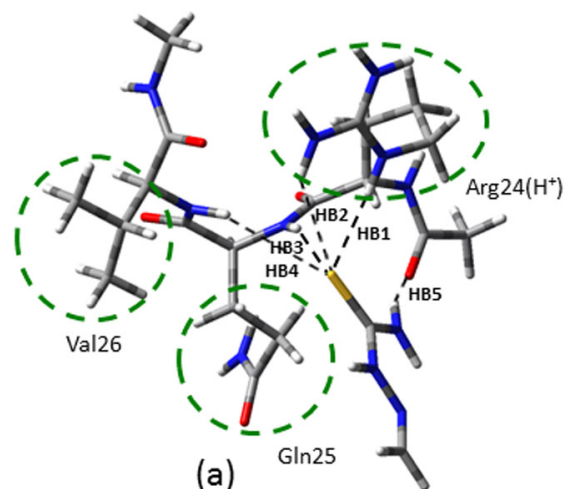

(a)

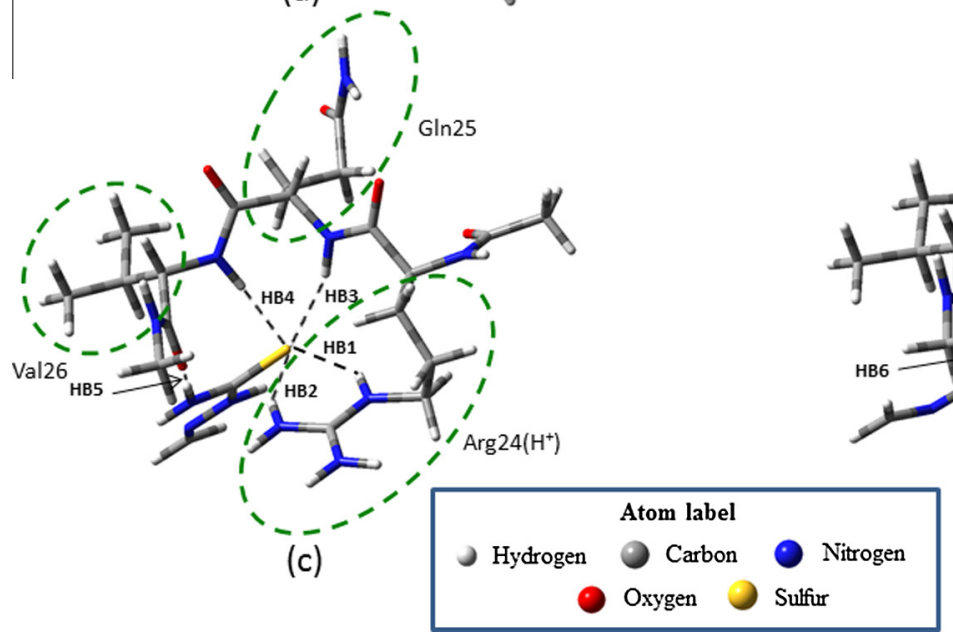

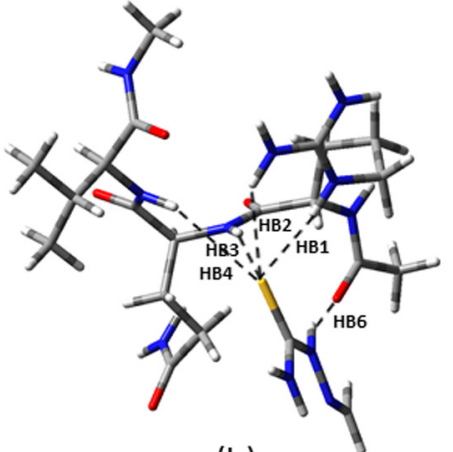

(b)

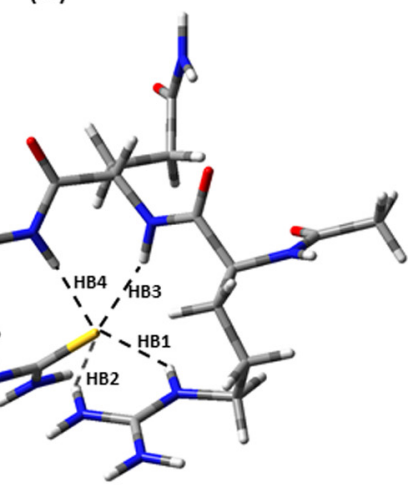

(d)

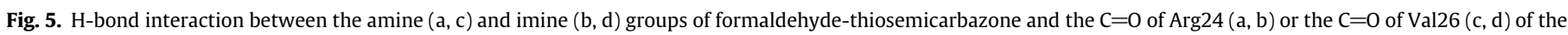
protonated tripeptide model $\mathrm{CH}_{3} \mathrm{CO}-\mathrm{Arg} 24\left(\mathrm{H}^{+}\right)-\mathrm{Gln} 25-\mathrm{Val} 26-\mathrm{NHCH}_{3}$.

and Val26, as indicated in Fig. 5. by HB1-HB4), whereas the (underlined) hydrogen atoms in $\mathrm{NH}_{2}$ or $\mathrm{NHNCH}_{2}$ groups can interact with the peptide $\mathrm{C}=0$ group of the aminoacids Arg24 or Val26.
The mode of interaction for formaldehyde-semicarbazone is not shown in Fig. 5 because it is similar to that for formaldehydethiosemicarbazone, expect by the absence of interaction with the 
Table 2

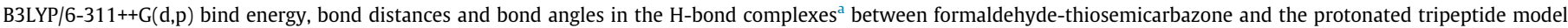
$\mathrm{CH}_{3} \mathrm{CO}-\mathrm{Arg} 24\left(\mathrm{H}^{+}\right)-\mathrm{Gln} 25-\mathrm{Val} 26-\mathrm{NHCH}_{3}$.

\begin{tabular}{|c|c|c|c|c|}
\hline \multirow[t]{2}{*}{ Parameter } & \multicolumn{2}{|c|}{$\left(\operatorname{Res}_{\mathrm{i}}\right) \mathrm{NH} \cdots$ Ligand $\cdots \mathrm{O}=\mathrm{C}(\operatorname{Arg} 24)^{\mathrm{c}}$} & \multicolumn{2}{|c|}{$\left(\operatorname{Res}_{\mathrm{i}}\right) \mathrm{NH} \cdots$ Ligand $\cdots \mathrm{O}=\mathrm{C}\left(\right.$ Val26) ${ }^{\mathrm{c}}$} \\
\hline & $\begin{array}{l}\cdots \mathrm{S}=\mathrm{C}\left(\mathrm{NHNCH}_{2}\right) \mathrm{NH}_{2} \cdots \\
\text { Fig. } 5 \mathrm{a}\end{array}$ & $\begin{array}{l}\cdots \mathrm{S}=\mathrm{C}\left(\mathrm{NHNCH}_{2}\right) \mathrm{NH}_{2} \cdots \\
\text { Fig. } 5 \mathrm{~b}\end{array}$ & $\begin{array}{l}\cdots \mathrm{S}=\mathrm{C}\left(\mathrm{NHNCH}_{2}\right) \mathrm{NH}_{2} \cdots \\
\text { Fig. } 5 \mathrm{c}\end{array}$ & $\begin{array}{l}\text { ․ }=\mathrm{S}=\mathrm{C}\left(\mathrm{NHNCH}_{2}\right) \mathrm{NH}_{2} \ldots \\
\text { Fig. } 5 \mathrm{~d}\end{array}$ \\
\hline$\Delta E_{\mathrm{H} \text {-bond }}\left(\mathrm{kcal} \mathrm{mol}^{-1}\right)$ & -29.86 & -30.55 & -24.71 & -23.41 \\
\hline \multicolumn{5}{|l|}{$\mathrm{R}_{\mathrm{H} \text {-bond }}(\AA) ; \mathrm{A}_{\mathrm{N}-\mathrm{H} \ldots \mathrm{S}}$ (degree) } \\
\hline \multirow[t]{2}{*}{ HB1(Arg24)N11H44 ‥S70 } & $2.298^{\mathrm{d}}$ & $2.266^{\mathrm{d}}$ & 2.663 & 2.666 \\
\hline & $167.6^{\mathrm{d}}$ & $167.5^{\mathrm{d}}$ & 148.2 & 147.8 \\
\hline \multirow{2}{*}{ HB2 (Arg24)N14H47 ..S70 } & 2.895 & 2.856 & $2.378^{d}$ & $2.360^{d}$ \\
\hline & 140.3 & 140.2 & $158.9^{\mathrm{d}}$ & $159.2^{\mathrm{d}}$ \\
\hline \multirow[t]{2}{*}{ HB3 (Gln25)N15H58 ‥S70 } & $2.519^{d}$ & $2.484^{\mathrm{d}}$ & 2.770 & 2.761 \\
\hline & $156.5^{\mathrm{d}}$ & $157.2^{\mathrm{d}}$ & 157.5 & 157.4 \\
\hline \multirow[t]{2}{*}{ HB4 (Val26)N24H67...S70 } & 3.221 & 3.181 & 2.729 & 2.701 \\
\hline & 158.0 & 158.4 & 157.6 & 157.6 \\
\hline \multirow{2}{*}{ HB5 N72 $\underline{\mathrm{H} 73} \cdots \mathrm{O}=\mathrm{C}\left(\operatorname{Res}_{\mathrm{j}}\right)$} & 1.938 & & 1.942 & \\
\hline & 154.2 & & 173.9 & \\
\hline \multirow{2}{*}{ HB6 N75 $\underline{\mathrm{H} 76} \cdots \mathrm{O}=\mathrm{C}\left(\operatorname{Res}_{\mathrm{j}}\right)$} & & 2.103 & & 1.963 \\
\hline & & 153.0 & & 172.2 \\
\hline \multirow[t]{2}{*}{$\mathrm{C} 78 \underline{\mathrm{H} 80} \cdots \mathrm{O}=\mathrm{C}\left(\operatorname{Res}_{\mathrm{j}}\right)$} & & 2.314 & & 2.916 \\
\hline & & 140.8 & & 129.6 \\
\hline
\end{tabular}

\footnotetext{
a Hydrogen atom involved in the H-bond is underlined.

b The H-complexes structures are available in the Supplementary data.

c Ligand = formaldehyde-thiosemicarbazone.

d Donohue's criteria for classifying $\mathrm{N}-\mathrm{H} \cdots \mathrm{S}=\mathrm{C}$ as $\mathrm{H}$-bond.
}

carbonyl group of Val26. Indeed, for the formaldehyde-semicarbazone system, two initial geometries where the hydrogen atoms in the $\mathrm{NH}_{2}$ or in the $\mathrm{NHNCH}_{2}$ groups were initially making $\mathrm{H}$-bond interaction with the $\mathrm{C}=\mathrm{O}$ of Val26 have moved during the optimization procedure toward a final structure where these hydrogen atoms make $\mathrm{H}$-bond interaction with the $\mathrm{C}=0$ group of Arg24. It is interesting to note that in a similar way for the formaldehyde-semicarbazone, the carbonyl moiety in the palmitic acid is reported to interact only with the $\mathrm{C}=\mathrm{O}$ group of $\operatorname{Arg} 24$ [16]. In Table 2 we show geometric and energetic parameters related to the model system formaldehyde-thiosemicarbazone $\mathrm{H}$-bonded to the protoned tripeptide model $\mathrm{CH}_{3} \mathrm{CO}-\operatorname{Arg} 24\left(\mathrm{H}^{+}\right)-\mathrm{Gln} 25-\mathrm{V}$ al26- $\mathrm{NHCH}_{3}$.

Considering the Donohue's criteria for classifying $\mathrm{N}-\mathrm{H} \cdots \mathrm{S}=\mathrm{C}$ as a H-bond, i.e., H . . S distance lower than $2.75 \AA$ And $\mathrm{N}-\mathrm{H}$. . S S planar angle larger than $155^{\circ}$ [34], one can observe in Table 2 (see values in bold) that, although four $\mathrm{N}-\mathrm{H}$ bonds pointing to the sulfur atom of formaldehyde-thiosemicarbazone, only one $\mathrm{N}-\mathrm{H}$ bond satisfy these criteria when it interacts to the $\mathrm{C}=\mathrm{O}$ group of Val26 (namely the (Arg24)N14H47), whereas two of them satisfy these criteria when it interacts with the $\mathrm{C}=\mathrm{O}$ group of Arg24 (namely $(\operatorname{Arg} 24) \mathrm{N} 11 \mathrm{H} 44$ and (Gln25)N15H58). It can explain why the H-complexes involving the $C=0$ group in Val26 are $6-7 \mathrm{kcal} \mathrm{mol}^{-1}$ less stable than the corresponding $C=0$ group in $\operatorname{Arg} 24$. In the last case, i.e., when formaldehyde-thiosemicarbazone interacts with the $\mathrm{C}=0$ group of Arg24 through the hydrogen atom of $\mathrm{NHNCH}_{2}$ there are two compatible H-bond interactions: $\mathrm{N} 75 \underline{\mathrm{H} 76} \cdots \mathrm{O}=\mathrm{C}(\operatorname{Arg} 24)=2.103 \AA$ [35] and $\mathrm{C} 78 \underline{\mathrm{H} 80} \cdots \mathrm{O}=\mathrm{C}(\operatorname{Ar} \mathrm{g} 24)=2.314 \AA[36,37]$, whereas with the $\mathrm{NH}_{2}$ group there is only one: $\mathrm{N} 72 \underline{\mathrm{H} 73} \cdots \mathrm{O}=\mathrm{C}(\operatorname{Arg} 24)=1.938 \AA$. Besides, in this comparison the H-bond distances $($ Arg24)N11H44 ‥S70 and (Gln25)N15H58 ‥S70 are lightly shorter than for the hydrogen donor specie $\mathrm{N}_{2}$. It probably explain the light preference of $\mathrm{NHNCH}_{2}$ than to $\mathrm{NH}_{2}$ group for interacting with the $\mathrm{C}=\mathrm{O}$ group of $\mathrm{Arg} 24$. For the most stable $\mathrm{H}$-complex, the predicted (Arg24)N11H44…S70 H-bonds, $2.266 \AA$, is lower than the experimentally observed $\mathrm{NH} \cdots \mathrm{S}$ distances in crystals of trithiocyanuric acids (c.a. $2.5 \AA$ ) [38] and also lower than the average experimental $\mathrm{N}-\mathrm{H} \cdots \mathrm{S}=\mathrm{C}$ bond distance, $2.56 \AA$ obtained from seven thio containing crystals [39].

\section{Conclusion}

A set of phenyl- and phenoxymethyl-(thio)semicarbazone derivatives with activity against the larvae of $A$. aegypti in L4 was studied theoretically and by NMR experiments. The electronic structure calculations at B3LYP/6-311++G(d,p) level of theory showed that the partial $\mathrm{CN}$ double bond in the anti is more stable and exhibits low dipole moment than in the syn conformation. The value and orientation of the dipole moment change from the phenyl- to the phenoxymethyl-thiosemicarbazone derivatives as well as with the presence of halogen atoms at para position of the aromatic ring. Such changes in the dipole moment are probably related to the improved larvicidal activity of the phenoxymethyl-thiosemicarbazone over the phenyl-thiosemicarbazone. From the comparison between experimental and calculated $\mathrm{NN}-\mathrm{H}^{1} \mathrm{H}$ chemical shift of (thio)semicarbazone derivatives in DMSO- $d_{6}$ it is possible to establish that the characteristic unshielded $\mathrm{NN}-\mathrm{H}$ sign is mainly due to its $\mathrm{H}$-bond interaction with residual water contained in DMSO samples. Water is theoretically predicted to interacts with semicarbazone derivatives mainly as hydrogen donor whereas with thiosemicarbazone derivatives mainly as hydrogen acceptor. This prediction is supported by bidimensional ${ }^{1} \mathrm{H}$ NMR experiments. The hypothesis of thiosemicarbazone derivatives interact to turn residues of AeSCP-2 (as palmitic acid do) was corroborated by the H-complexes formed between the representative model systems formaldehydethiosemicarbazone and the protonated tripeptidic system $\mathrm{CH}_{3} \mathrm{CO}-\mathrm{Arg} 24\left(\mathrm{H}^{+}\right)-\mathrm{Gln} 25-\mathrm{Val} 26-\mathrm{NHCH}_{3}$.

\section{Author contributions}

MNR coordinated the first electronic structure calculations and advised AGS on the analysis of the results. JWPE synthesized compounds 1-4,6-17 and wrote part of the manuscript. ADTO synthesized compound 18. DRM revised the synthetic experimental methodology. ACLL and DJB coordinated the synthesis and spectroscopic characterization of all compounds. FH developed, analyzed, interpreted the NMR spectra and revised the manuscript. KMMJr discussed the electronic structure results and revised the manuscript and JBPS was involved in the electronic structure calculations, comparison between calculated and experimental results 
and wrote the manuscript. All authors read and agreed with the final version of this manuscript.

\section{Acknowledgments}

The authors thank FACEPE/CNPq/PRONEX, FACEPE/PPSUS-2008 and Dengue Institute/CNPq for supporting this work. J.B.P. da Silva thanks CNPq a scholarship for developing part of the computational work in the Prof. Kenneth Merz Jr group at the University of Florida. A.G da Silva thanks CAPES and J.W.P. Espíndola and A.D.T. de Oliveira thank FACEPE for their Ph.D. scholarships.

\section{Appendix A. Supplementary data}

Supplementary data associated with this article can be found, in the online version, at http://dx.doi.org/10.1016/j.molstruc.2015.03. 011. These data include MOL files and InChiKeys of the most important compounds described in this article.

\section{References}

[1] M.B. Nathan, R. Dayal-Drager, M. Guzman, Chapter 1: Epidemiology, Burden of Disease and Transmission, New ed., World Health Organization. Dengue: Guidelines for Diagnosis, Treatment, Prevention and Control, WHO Library Cataloguing-in-Publication Data, Geneva, 2009, pp. 3-17.

[2] D.J. Gubler, Trends in Microbiol. 10 (2002) 100-103, http://dx.doi.org/10.1016/ S0966-842X(01)02288-0.

[3] D. Normile, Science 342 (2013) 415, http://dx.doi.org/10.1126/science.342. 6157.415.

[4] J.G. Rigau-Perez, M.K. Laufer, Clin. Infect. Dis. 42 (2006) 1241-1246, http:// dx.doi.org/10.1086/501355.

[5] P.V. Effler, L. Pang, P. Kitsutani, V. Vorndam, M. Nakata, T. Ayers, J. Elm, T. Tom, P. Reiter, J.G. Rigau-Perez, J.M. Hayes, K. Mills, M. Napier, G.G. Clark, D.J. Gubler, Emerg. Infect. Dis. 11 (2005) 742-749, http://dx.doi.org/10.3201/ eid1105.041063.

[6] J.L. Kyle, E. Harris, Annu. Rev. Microbiol. 62 (2008) 71-92, http://dx.doi.org/ 10.1146/annurev.micro.62.081307.163005.

[7] N.W. Beebe, R.D. Cooper, P. Mottram, A.W. Sweeney, PLOS Negl. Trop. Dis. 3 (2009) 1-9, http://dx.doi.org/10.1371/journal.pntd.0000429.

[8] M.J.P. Delgado, J.M. Gutierrez, L.B. Radic, T. Maretic, S. Zekan, T. Avšič-Županc, E.S. Aymar, A. Trilla, J.G. Brustenga, Emerg. Infect. Dis. 14 (2008) 1329-1330, http://dx.doi.org/10.3201/eid1408.080068.

[9] R. Allwinn, Med. Microbiol. Immunol. 200 (2011) 155-159, http://dx.doi.org/ 10.1007/s00430-011-0185-2.

[10] M.A.V. Melo-Santos, J.J.M. Varjal-Melo, A.P. Araújo, T.C.S. Gomes, M.H.S. Paiva, L.N. Regis, A.F. Furtado, T. Magalhaes, M.L.G. Macoris, M.T.M. Andrighetti, C.F.J Ayres, Acta Trop. 113 (2010) 180-189, http://dx.doi.org/10.1016/ j.actatropica.2009.10.015.

[11] J.A. Suya, D.S. Shepard, M.-S. Chang, M. Caram, S. Hoyer, D. Socheat, N. Chantha, M.B. Nathan, Trop. Med. Int. Health 12 (2007) 1026-1036, http://dx.doi.org/ 10.1111/j.1365-3156.2007.01889.x.

[12] J.W.P. Espíndola, Master Dissertation in Pharmacy Science, Universidade Federal de Pernambuco, 2010.

[13] J.B.P. da Silva, D.M.A. F. Navarro, A.G. da Silva, G.K N. Santos, K.A. Dutra, D. R. Moreira, M.N. Ramos, J.W. P. Espíndola, A.D.T. de Oliveira, D.J. Brondani, A.C.L. Leite, M.Z. Hernandes, V.R.A. Pereira, L.F. da Rocha, M.C.A.B. de Castro, B.C. de Oliveira, Q. Lan, K.M. Merz Jr., Eur. J. Med. Chem., 2015 (in press).

[14] C.A. Kunos, T.M. Sherertz, Front. Oncol. 4 (2014) 1-5, http://dx.doi.org/ 10.3389/fonc.2014.00184. article 184 .
[15] C. Hansch, P.P. Maloney, T. Fujita, R.M. Muir, Nature 194 (1962) 178-180, http://dx.doi.org/10.1038/194178b0.

[16] D.H. Dyer, S. Lovell, J.B. Thoden, H.M. Holden, I. Rayment, Q. Lan, J. Biol. Chem. 278 (2003) 39085-39091, http://dx.doi.org/10.1074/jbc.M306214200.

[17] A.D. Becke, J. Chem. Phys. 98 (1993) 5648-5652, http://dx.doi.org/10.1063/ 1.464913.

[18] T. Clark, J. Chandrasekhar, G.W. Spitznagel, P.V.R. Schleyer, J. Comp. Chem. 4 (1983) 294-301, http://dx.doi.org/10.1002/jcc.540040303.

[19] M.J. Frisch, J.A. Pople, J.S. Binkley, J. Chem. Phys. 80 (1984) 3265-3269, http:// dx.doi.org/10.1063/1.447079.

[20] A. Halkier, W. Klopper, T. Helgaker, P. Jørgensen, P.R. Taylor, J. Chem. Phys. 111 (1999) 9157-9167, http://dx.doi.org/10.1063/1.479830.

[21] D.A. McQuarrie, Statistical Mechanics, University Science Books, Sausalito, CA, 2000.

[22] GaussView, Version 5, R. Dennington, T. Keith, J. Millam, Semichem Inc., Shawnee Mission KS, 2009.

[23] K. Wolinski, J.F. Hilton, P. Pulay, J. Am. Chem. Soc. 112 (1990) 8251-8260, http://dx.doi.org/10.1021/ja00179a005.

[24] M.J. Frisch, G.W. Trucks, H.B. Schlegel, G.E. Scuseria, M.A. Robb, J.R. Cheeseman, G. Scalmani, V. Barone, B. Mennucci, G.A. Petersson, H. Nakatsuji, M. Caricato, X. Li, H.P. Hratchian, A.F. Izmaylov, J. Bloino, G. Zheng, J.L. Sonnenberg, M. Hada, M. Ehara, K. Toyota, R. Fukuda, J. Hasegawa, M. Ishida, T. Nakajima, Y. Honda, O. Kitao, H. Nakai, T. Vreven, J.A. Montgomery, J.E. Peralta, F. Ogliaro, M. Bearpark, J.J. Heyd, E. Brothers, K.N. Kudin, V.N. Staroverov, R. Kobayashi, J. Normand, K. Raghavachari, A, Rendell, J.C. Burant, S.S. Iyengar, J. Tomasi, M. Cossi, N. Rega, J.M. Millam, M. Klene, J.E. Knox, J.B. Cross, V. Bakken, C. Adamo, J. Jaramillo, R. Gomperts, R.E. Stratmann, O. Yazyev, A.J. Austin, R. Cammi, C. Pomelli, J.W. Ochterski, R.L. Martin, K. Morokuma, V.G. Zakrzewski, G.A. Voth, P. Salvador, J.J. Dannenberg, S. Dapprich, A.D. Daniels, O. Farkas, J.B. Foresman, J.V. Ortiz, J. Cioslowski, D.J. Fox, Gaussian 09, Revision A.02, Gaussian Inc, Wallingford CT, 2009.

[25] M.B. Ferrari, S. Capacchi, G. Reffo, G. Pelosi, P. Tarasconi, R. Albertini, S. Pineli, P. Lunghi, J. Inorg. Biochem. 81 (2000) 89-97, http://dx.doi.org/10.1016/S01620134(00)00087-8.

[26] I.C. Mendes, L.R. Teixeira, R. Lima, H. Beraldo, N.L. Speziali, D.X. West, J. Mol. Struct. 559 (2001) 355-360, http://dx.doi.org/10.1016/S0022-2860(00)007298.

[27] H. Beraldo, R. Lima, L.R. Teixeira, A.A. Moura, D.X. West, J. Mol. Struct. 559 (2001) 99-106, http://dx.doi.org/10.1016/S0022-2860(00)00690-6.

[28] G.M. Lima, J.L. Neto, H. Berado, H.G.L. Siebald, D.J. Duncalf, J. Mol. Struct. 604 (2002) 287-291, http://dx.doi.org/10.1016/S0022-2860(01)00664-0.

[29] H.-K. Fun, C.S. Yeap, M. Padaki, S. Malladi, A.M. Isloor, Acta Cryst. E65 (2009) o1619-o1620, http://dx.doi.org/10.1107/S1600536809022521.

[30] J.A. Lessa, I.C. Mendes, P.R.O. da Silva, M.A. Soares, R.G. dos Santos, N.L. Speziali, N.C. Romeiro, E.J. Barreiro, H. Beraldo, Eur. J. Med. Chem. 45 (2010) 5671-5677, http://dx.doi.org/10.1016/j.ejmech.2010.09.021.

[31] R.L. Lima, L.R.S. Teixeira, T.M.G. Carneiro, H. Beraldo, J. Braz. Chem. Soc. 10 (1999) 184-188, http://dx.doi.org/10.1590/S0103-50531999000300005.

[32] I.C. Mendes, L.R. Teixeira, R. Lima, T.G. Carneiro, H. Beraldo, Trans. Met. Chem. 24 (1999) 655-658, http://dx.doi.org/10.1023/A:1006918604467.

[33] R. Ellson, R. Stearns, M. Mutz, C. Brown, B. Browning, D. Harris, S. Qureshi, J. Shieh, D. Wold, Com. Chem. High T. Scr. 8 (2005) 489-498, http://dx.doi.org/ $10.2174 / 1386207054867382$.

[34] J. Donohue, J. Mol. Biol. 45 (1969) 231-235, http://dx.doi.org/10.1016/00222836(69)90102-8.

[35] I.Y. Torshin, I.T. Weber, R.W. Harrison, Protein Eng. 15 (2002) 359-363, http:// dx.doi.org/10.1093/protein/15.5.359.

[36] T. Steiner, W. Saenger, J. Am. Chem. Soc. 114 (1992) 10146-10154, http:// dx.doi.org/10.1021/ja00052a009.

[37] Y. Gu, T. Kar, S. Scheiner, J. Am. Chem. Soc. 121 (1999) 9411-9422, http:// dx.doi.org/10.1021/ja991795g.

[38] V.R. Pedireddi, S. Chatterjee, A. Ranganathan, C.N.R. Rao, J. Am. Chem. Soc. 119 (1997) 10867-10868, http://dx.doi.org/10.1021/ja972289z.

[39] T.T. Tran, A.W. Burgess, H. Treutlein, J. Perich, J. Peptide Res. 58 (2001) 67-78, http://dx.doi.org/10.1034/j.1399-3011.2001.00898.x. 